\title{
On the Anatomy of some Tubers.
}

\author{
BY \\ T. REED, A.R.C.S. \\ Biology Department : St. Mary's Hospilal Medical School.
}

\section{With Plates XLII and XLIII and four Diagrams in the Text.}

TH

$\mathrm{HE}$ investigation of the anatomical structure of tubers has been much neglected. Hitherto no account appears to have been published dealing with the anatomy of the potato, Solanum tuberosum, or with that of the artichoke, Helianthus tuberosus.

Several attempts have been made to determine the causes which bring about tuberization in the potato. In a long series of papers N. Bernard (1) has attempted to show that tuberization in the potato is a result of the infection of the plant by a fungus. By inoculating the cortex of the roots of young plants of $S$. tuberosum with the spores of the fungus Fusarium, he claims that he obtains a greater yield of tubers than he does in the case of plants which are not artificially inoculated with the fungus spores. He does not explain why infection should cause tuberization in a totally different part of the plant from that which is actually infected. It will be difficult to explain why infection of the root by the fungus should cause tuberization in the stems, for in no case has the fungus been traced from the root to the tubers. In the case of attacks of fungi on plant tissue it is usual to find the part actually infected becoming meristematic and forming tubercular growths such as we get in the cases of galling, witches' brooms, \&c. Bernard tentatively suggests that it may be an action a distance by the fungus, brought about by its giving rise to soluble products which in some mysterious way cause the underground stems to swell up and accumulate vast reserves of carbohydrates, \&c.

H. Jumelle (9) has caused some doubt to be thrown on the work of Bernard. Repeating some of Bernard's experiments, Jumelle does not appear to confirm his results, and he says that the results, in his opinion, are not sufficiently clear to convince him of the conclusions drawn by Bernard.

In Bernard's third experiment he describes a case in which the potatoes were grown en pleine terre. The first lot were assured of infection by being

[Annals of Botany, Vol. XXIV. No. XCV. July, 1910.] 
manured with dung which was contaminated with Fusarium; in the second lot the infection was irreguliere et tardive. Since he obtains a greater yield of tubers from the first lot than he does from the second, the inference is drawn that the infection by Fusarium is responsible for the difference in yield. Bernard appears to have overlooked the fact that the manuring of the soil of the first lot of tubers would probably account for very considerable differences between the harvests of the two lots. This probability is strengthened in view of the work of L. Dufour (6), who has shown that plants of S. Commersonii are very susceptible to changes in the physical and chemical condition of the soil. Dufour concludes that moist earth favours the production of tubers, and that sandy soil is more favourable to their formation than is sandy soil mixed with varying percentages of calcium.

None of these authors has given us any account of the anatomical structure of the potato, and very few accounts of the anatomy of other tubers are available.

E. Bucherer (2) has dealt with the anatomy of several tubers of Dioscoreaceae, but he deals more particularly with the origin of the tuber and the features of its vascular anatomy, and he makes no reference to the tissues which are concerned with the formation of the tuberous tissue.

A. De Bary (4), dealing with the tubers of Dioscoreaceae, states that in those tubers which exhibit secondary thickening the origin of the cambium is unknown. In the specimens investigated, however, a cambium surrounds the whole lateral surface of the tuber inside the cortex. This cambium gives rise to interfascicular tissue consisting of thin-walled parenchyma which forms the main mass of the tuber.

Leclerc du Sablon (10) also deals with the tuber of a member of the Dioscoreaceae, Tamus communis. He deals more particularly with its development and morphological nature than with its anatomy or the origin of the tuberous tissue, and his figures give us no clue as to the tissue which is responsible for forming the main mass of the tuber.

Miss E. Dale (3), dealing with the tuber of Dioscorea sativa, mentions that it is made up of parenchymatous tissue, but does not discuss its origin.

Marcel Dubard and Renè Viguier (5) give an interesting account of the tuber of Euphorbia Intisy. This is a root tuber. The root shows a central cylinder consisting of a hexarch stele. Secondary thickening commences in the usual way by a cambium which surrounds the xylem portions of the vascular cylinder. This cambium, however, forms few secondary xylem elements, but gives rise to long radial rows of parenchyma cells which compose the bulk of the tuber. At infrequent intervals a few wood elements may be formed, but owing to the very extensive development of parenchyma these become cut off as 'illots vasculaires'. The pith also contributes to the tuberous tissue.

Theo. Holm (7) gives an account of the root tubers of Rhexia virginica. 
Whilst he does not deal particularly with the origin of the tuberous tissue, his figures suggest that it is formed from wood parenchyma of the secondary hadrome or wood. It is worth noticing that although these tubers are the principal means of propagation of this plant, neither the tuberous tissue nor the cortex contains any starch, and other deposits appear to be scarce. The cortex also appears to contribute some part of the tuberous tissue.

F. J. F. Shaw (11) describes the anatomy of the tuberous seedlings of Araucaria Bidwillii, but he gives us no account of how the tuberous tissue arises.

\section{Anatomy of Tubers of Solanum tuberosum.}

The tubers of S. tuberosum arise as terminal swellings on long underground stems or stolons. These stems arise in the axils of the lower leaves of the main shoot and grow more or less horizontally outwards, and sooner or later they swell up at their tips to form tubers. That these structures are stems is shown by their origin and their anatomical and morphological structure.

The plants used in this investigation were grown in soil, and at various stages of their development tubers were cut off and preserved in alcohol.

To determine the course of the vascular bundles in the tuber, series of transverse sections were cut by hand from the stolon to the tip of the tuber.

The stolon presents a typical stem structure. There is a ring of bundles consisting of four larger groups of xylem elements with a few smaller groups scattered between them; each group is accompanied on its outer side by a group of phloem elements. Each bundle is also accompanied on its inner or medullary side by a group of phloem elements, so that the structure of the bundles is bicollateral, a structure which appears to be quite typical for the Solanaceae (4). The vascular cylinder is surrounded by an easily recognized endodermis (Pl. XLII, Fig. I, En.). It is worthy of notice that this endodermis is entirely devoid of starch grains. This appears remarkable when one is reminded that the cortex and pith contain very abundant quantities of starch grains. This absence of starch from the endodermis of the stolon of S. tuberosum is remarkable in that in most plants the endodermis is the tissue which almost invariably contains starch. It may possibly be explained that the absence of starch is due to the fact that the whole of the protoplasm of the endodermal cells is used up in their formation, for Millon's test and the xanthoproteic reaction failed to reveal the presence of protoplasm. Since then all the protoplasm is apparently used up in the formation of the cells, in their adult stage they would be incapable of any further activity.

The endodermis is surrounded by about eight or ten layers of parenchymatous cortical cells. These parenchymatous cells of the cortex contain abundant starch grains and protoplasm, and usually a nucleus as well. The 
pith is composed of large parenchymatous cells, and these also contain large quantities of starch grains. The outer surface of the stolon is covered by a single-layered epidermis, the cells of which have a thin cuticle on their outer surface. There is no development of cork on the stolon.

The change from underground stolon to tuber is quite abrupt; there is no gradual transition from stolon to tuber such as obtains in the case of
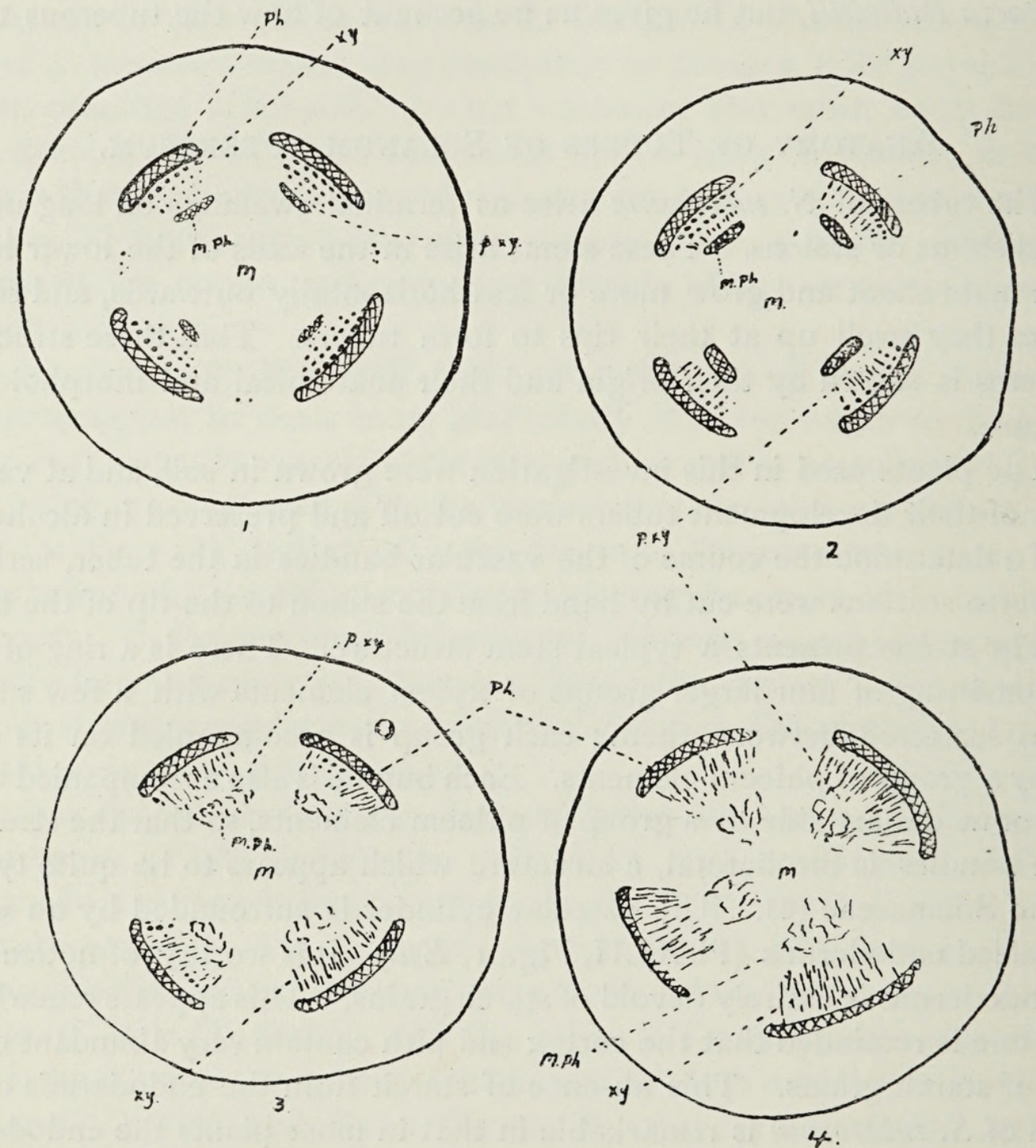

Diagram I. M., medulla. M.Ph, medullary phloem. p.xy., protoxylem. $x y$. , xylem. Ph., phloem.

Helianthus tuberosus. This circumstance makes it difficult to trace clearly the course of the vascular bundles from stolon to tuber.

Passing from the stolon to the base of the tuber it will be seen (Diagram I, Fig. I) that the ring of bundles begins to lose its definite arrangement into groups, as seen in transverse section, and to become 'sprayed' outwards (Diagram I, Figs. 2 and 3). Thus it will be seen that a transverse section of a tuber at this level would cut the vascular elements in an oblique direction. Still farther in the tuber the 'spraying' has gone 
on to such an extent that the wood elements are now seen to be cut longitudinally even in a transverse section (Diagram I, Fig. 4).

This derangement of the vascular tissue is a direct result of the tuberization of the stolon, and is brought about in the following manner:-

Just about the region where the stolon joins on to the tuber it will be noticed (Pl. XLII, Fig. 4) that the pith cells are becoming meristematic. Transverse sections a little farther in the tuber show that almost every cell of the pith is dividing. As a result of the activity of these pith cells a very considerable amount of parenchymatous tissue is added to the pith. It is this increase of medullary tissue which is responsible for the deranging of the vascular tissue. As the medullary cells continue their divisions they produce what is essentially a wedge of tissue which forces the xylem elements out of their normally vertical course and compels them to pursue a more or less oblique course.

Diagram II shows the effect of the meristematic medulla on the strands of xylem.

It must be fairly obvious that the large increase in quantity of the pith elements, and the consequent dilatation of the stolon to form a tuber, would under ordinary circumstances also result in a rupture of the cortex, so that pari passu there is a corresponding division in the cells of the cortex.

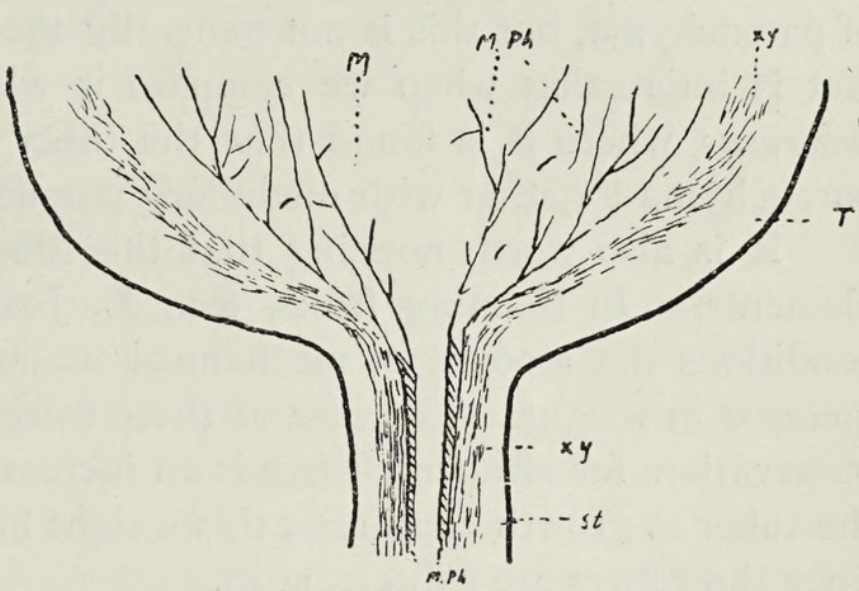

DiAgRam II. $M$., meristematic medulla. $x y$., xylem. st., stolon. T., tuber. M.Ph., medullary phloem. Longitudinal section of tuber at junction with stolon.

It is thus seen that the pith contributes a very large portion to the tuberous tissue of the tuber.

It now remains to trace the distribution of the medullary phloem in the tuber.

The medullary phloem consists of the usual elements, sieve tubes, companion cells, and phloem parenchyma (PI. XLII, Figs. I and 2).

At the time when the medullary cells of the stolon begin to become meristematic it is seen that the parenchyma cells between the protoxylem of the bundle and the medullary phloem also commence to divide. Simultaneous with this the phloem parenchyma of the medullary phloem begins to divide. As a result of these divisions it is found that the medullary phloem becomes broken up into a large number of small strands isolated from each other by pockets of parenchyma (Pl. XLII, Fig. 3, and Diagram II, M.Ph.).

The phloem strands which are distributed amongst the medullary 
parenchyma cells pursue a very irregular course (Pl. XLII, Fig. 6). This is because the isolated strands are surrounded by meristematic cells which are not dividing at a uniform rate, so that in one region the strands will be pushed in one way and elsewhere in a different direction.

It is interesting to find that the medullary phloem is apparently used for the conduction of carbohydrates from the parent plant to the developing tuber. This conclusion can hardly be resisted when one considers the manner in which the phloem elements ramify amongst the tuberous elements of the medulla.

From the above it is seen that the tuber of $S$. tuberosum is built up from three kinds of tissue : (I) medulla, (2) phloem parenchyma, and (3) to a smaller extent, cortex. Xylem parenchyma does not contribute any considerable portion to the tuber. In some few cases it may be seen that the protoxylem is partly separated from the later-formed xylem by a wedge of parenchyma, but this is not generally the case (Pl. XLII, Fig. 4). This fact is interesting when we compare it with what obtains in Helianthus tuberosus, where it is found that the tuber is built up largely from xylem parenchyma together with medullary parenchyma.

It is also worth noticing that the tuber forms few, if any, new wood elements. In ripening fruits, \&c., L. Jost (8) states that under natural conditions the amount of mechanical tissue increases in proportion to the increase in weight. The case of these tubers is quite in harmony with this observation, for although there is an increase in the size and the weight of the tuber as growth continues, this weight has not to be borne by the plant, since the tubers are subterranean.

It will be recalled that the stolon which gives rise to the tuber was covered with a single-layered epidermis which has a slightly developed cuticle (P1. XLII, Fig. I, Ep.). Almost as soon as the stolon commences to dilate to form the tuber the cells of the hypoderma begin to divide tangentially and give rise to a cork cambium (Pl. XLII, Fig.5, $H_{y p}$.). In the case of S. Dulcamara, De Bary (4) states that the periderm arises in the epidermis, and Solereder (12) makes the same statement for some species of Solanum, but does not include any species of Solanum in the group in which the periderm arises in the sub-epidermal layer. It may possibly be that the more deep-seated origin of the cork cambium in the tuber of $S$. tuberosum is due to the fact that since the tuber is a subterranean structure, the epidermis would be liable to injury.

The cork cambium gives rise to several layers of cork on the outside and phelloderm on the inner side (Pl. XLII, Fig. $5 a, c k ., P$.) The development of a covering of cork for such a structure as the potato is almost a necessity, since the tuber contains a high percentage of water. 


\section{Anatomy of Tubers of Helianthus tuberosus.}

These tubers, like those of Solanum tuberosum, arise as swellings on underground stems, or stolons, which spring from the axils of scale leaves at the base of the main shoot. The stolon may at once swell up and become a tuber, or it may greatly elongate and give rise to a number of lateral tubers, finally terminating itself in a tuber. So far as these observations go this is different from what obtains in the potato, in that in the case of the latter the tubers do not arise laterally, as they may in $H$. tuberosus.

Figs. 7 and 8, Pl. XLII, show two young tubers. From these it will be seen that the tuber develops from the apex backwards.

The anatomical structure of an untuberized stolon is that of a typical dicotyledonous stem. Fig. 9, P1. XLII, shows a portion of such a stolon, as seen in transverse section. It consists of a ring of a dozen or more vascular bundles, each of which is accompanied on the outer side of the phloem by a group of sclerenchymatous fibres (P1. XLII, Fig. 9, scl.). Between the groups of xylem vessels there can be made out even at this stage small groups of xylem parenchyma (Pl. XLII, Fig. 9, xy.p.). The pith and cortex are made up of parenchymatous elements of the usual type.

As has been pointed out above, the transition from stolon to tuber is here very gradual, so that the manner in which the vascular elements are distributed in the tuber can be made out quite clearly. Tuberization is effected by two classes of tissue: (I) medulla, and (2) xylem parenchyma.

Just at the region where stolon structure passes into that of the tuber, the cells of the pith commence to divide tangentially (P1. XLIII, Fig. I2, M.). These divisions commence around the periphery of the medulla, and gradually extend inwards until almost the whole of the pith is involved.

The pith cells first enlarge considerably in a radial direction, and very soon tangential walls appear, and then the process is repeated again and again. As a result of these cell divisions in the medulla a very considerable amount of new parenchymatous tissue is added to the developing tuber. The cells resulting from the activity of this new meristem become arranged in definite radial rows (Pl. XLIII, Fig. I3).

For a time the parenchymatous cells of the medulla are the only cells which contribute to the formation of the tuber.

After a time, however, divisions are seen to commence in the xylem parenchyma (P1. XLII, Fig. I0, and Pl. XLIII, Fig. I 2, xy.p.). These divisions aremainly tangential, and first make their appearance in those pockets of xylem parenchyma which are nearest the protoxylem side of the bundle (PI.XLII, Fig. 10). As a consequence of these tangential divisions the protoxylem becomes pushed towards the centre of the stem. A little later other pockets of xylem parenchyma become similarly meristematic, with the result that the whole xylem portion of the bundle becomes separated into small groups 
of three or four vessels each, with intervening pockets of parenchyma. A transverse section of a portion of a tuber at this stage is shown in P1. XLIII, Fig. I4, where, as a result of the activity of the xylem parenchyma, the xylem appears to be broken up into islands $(x y$.). Strictly speaking, these are not true vascular islands, for in longitudinal section they are seen to be continuous, and not pinched off, as they would be were they true $\hat{i}$ lots vasculaires. The following diagram shows a longitudinal section of such a tuber:-

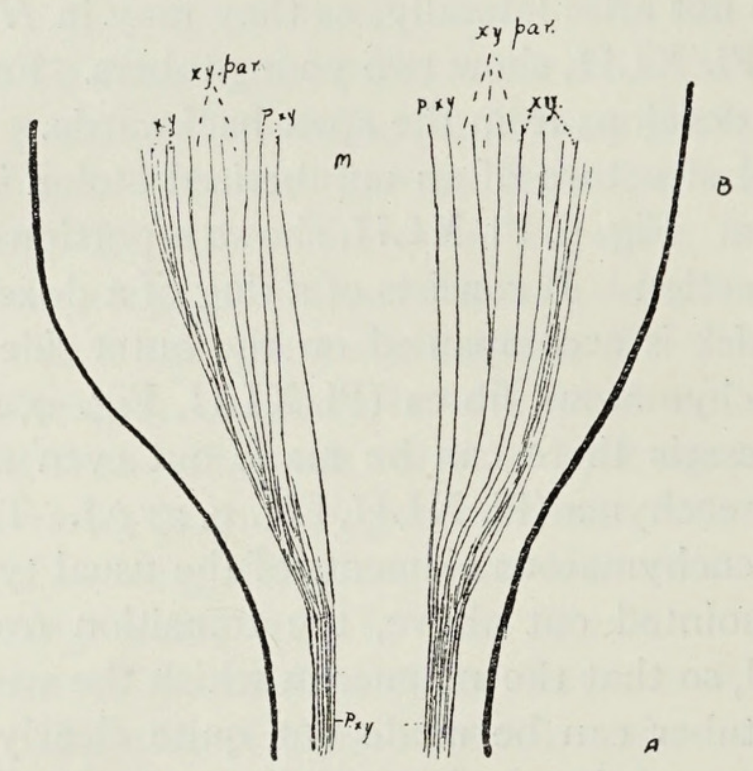

Diagram III. $x y$.par., xylem parenchyma. P.xy., protoxylem. $x y$., xylem. M., pith.

A series of transverse sections passing from $A$ to $B$ would present the features as shown in Diagram IV.

In the above description the term dilatation parenchyma has been purposely avoided. We have no evidence to show that the xylem parenchyma in this case is true dilatation parenchyma. This term is restricted to parenchyma which has ordinarily ceased to be active, but which may be recalled to activity by pathological conditions caused by fungal attacks, mechanical injury, \&c.

At the stage represented by Fig. 9, Pl. XLII, the cambium does not extend the whole way round the stem, but presently this extension is effected. The fascicular cambium produces very few new lignified elements, in which respect it agrees with $S$. tuberosum; most of the tissue to which it gives rise is xylem parenchyma which goes to form part of the tuberous tissue. The interfascicular cambium gives rise to no new xylem vessels, but restricts itself to the production of parenchymatous cells. The broad parenchymatous medullary ray tissue thus produced is arranged in regular radial rows as shown in P1. XLII, Fig. II, M.ry., and contributes largely to the tuberous tissue. A similar tissue is described as occurring in tubers of Euphorbia Intisy by MM. Dubard and Viguier (5). 
A few remarks might conveniently be added at this point with reference to the distribution of inulin in these tubers and its influence on cell division. The inulin is seen in young tubers as masses of sphere crystals surrounding the xylem elements of the bundles and 'welling' over into the immediately adjacent parenchyma. Tuberization does not appear to commence until these crystals are deposited in the young tuber, but as soon as
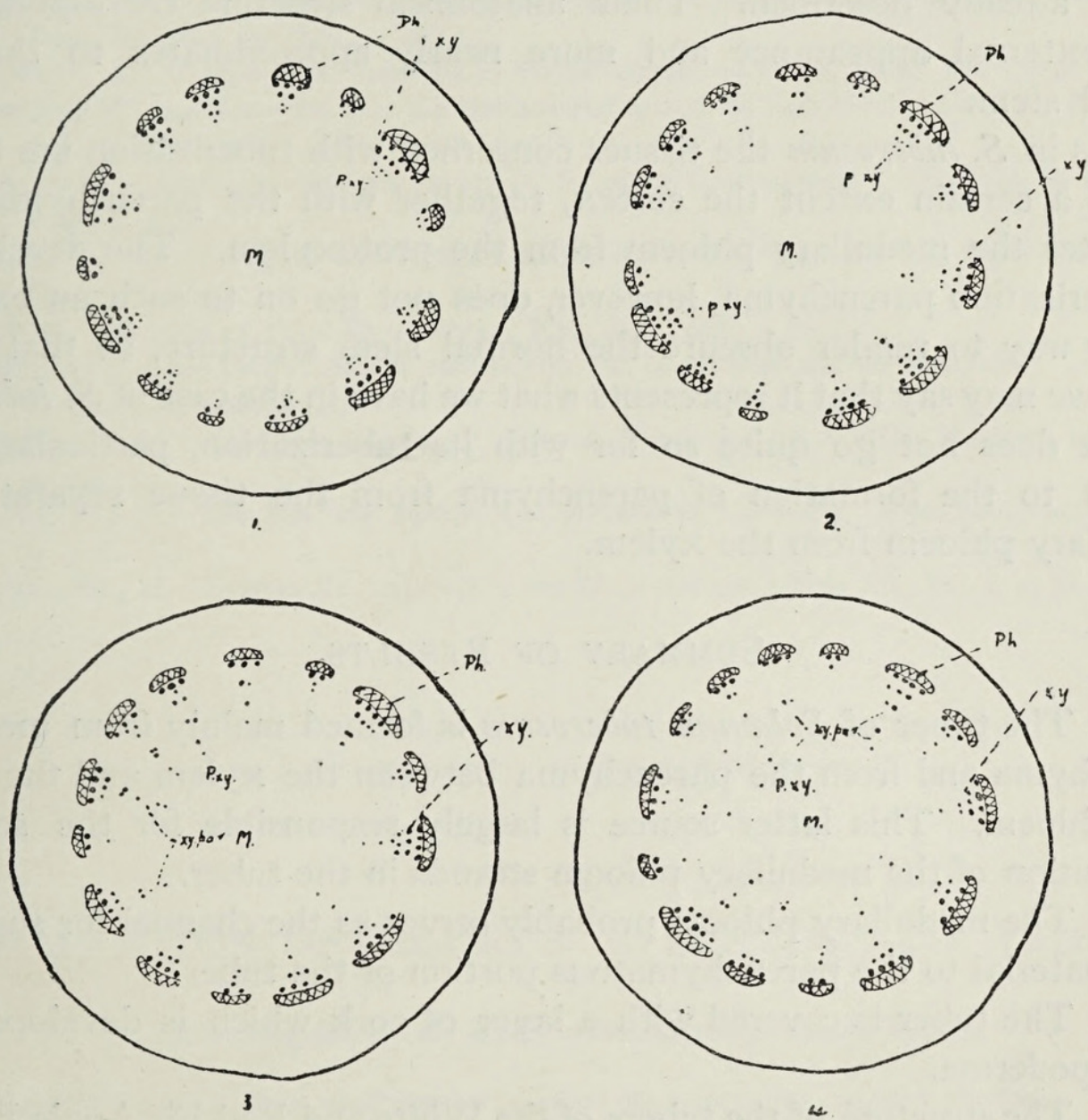

Diagram IV. Ph., ploem. $x y$. , xylem. P.xy., protoxylem. $M$. , pith. $x y . p a r$, xylem parenchyma.

they appear divisions commence in the parenchyma in their immediate vicinity. In some few cases the distribution of the inulin crystals was irregular; one side of the young tuber might contain an abundance of inulin, whilst the other side had comparatively little. When such was found to be the case the region devoid of inulin deposits had not become meristematic. It would appear then that the presence of the food reserve has a stimulating effect on the cells in which it is deposited, or it may possibly be the reverse, i. e. the activity of the cells demands a supply of food material.

From the above it is seen that the tuber of Helianthus tuberosus is made up of parenchyma derived from the activity of the medullary tissue and 
xylem parenchyma, together with parenchyma derived from the division of the interfascicular cambium. The cortex is not concerned with the addition of any appreciable amount of tissue to the tuber.

Tubers of the White and Red Fir Apple Potato (Sutton and Sons, Reading) were also examined. These tubers more nearly resemble ordinary stem structures in their external characters than does either of the two tubers already described. Their anatomical structure corresponds with their external appearance and more nearly approximates to that of a normal stem.

As in S. tuberosum the tissues concerned with tuberization are the pith and to a certain extent the cortex, together with the parenchyma which separates the medullary phloem from the protoxylem. The development of tuberization parenchyma, however, does not go on to such an extent as in any way to render obscure the normal stem structure, so that on the whole we may say that it represents what we have in the case of S. tuberosum, only it does not go quite so far with its tuberization, particularly with respect to the formation of parenchyma from the tissue separating the medullary phloem from the xylem.

\section{Summary of Results.}

I. The tuber of Solanum tuberosum is formed mainly from medullary parenchyma and from the parenchyma between the xylem and the medullary phloem. This latter source is largely responsible for the scattered distribution of the medullary phloem strands in the tuber.

2. The medullary phloem probably serves as the channel for supplying food material to the parenchymatous portion of the tuber.

3. The tuber is covered with a layer of cork which is developed from the hypoderma.

4. The structure of the tubers of the White and Red Fir Apple Potatoes is similar to that of $S$. tuberosum, but much less tuberous tissue is developed.

5. The tuber of Helianthus tuberosus is made up of medullary parenchyma, xylem and medullary ray parenchyma. In this latter respect it differs from $S$. tuberosum.

6. The distribution of inulin appears to have some influence on the meristematic activity of the cells.

7. In tubers of S. tuberosum and H. tuberosus few, if any, secondary lignified elements are formed.

In conclusion I wish to express my thanks to Prof. J. B. Farmer, F.R.S., for the suggestion that this work should be undertaken, and for his help and advice during the progress of this research; and also to Mr. Hales, the Curator of the Chelsea Physic Garden, where this work was carried out. 


\section{BIBLIOGRAPHY.}

1. Bernard, N. : Études sur la tubérisation. Rev. Gén. de Bot., t. xiv, I902, pp. 5, 58, ior, 170,219 , and 269 .

2. Bucherer, E. : Beiträge zur Morphologie und Anatomie der Dioscoreaceen. Bibliotheca Bot., Bd. iii, H. I6, I889.

3. Dale, E. : Origin, Development, and Morphological Nature of Aerial Tubers of Dioscorea sativa. Ann. Bot., vol. xv, I9oI, p. 49 I.

4. De Bary, A.: Comparative Anatomy of Phanerogams and Ferns. Eng. Ed. I884.

5. Dubard, M., and Viguier, R. : Le système radiculaire de l'Euphorbia Intisy. Rev. Gén. de Bot., t. xvii, 1905, p. 260.

6. Dufour, L.: Quelques expériences sur la Solanum Commersoni. Rev. Gén. de Bot., t. xix, I907, p. 353 .

7. Holm, T.: Morphological and Anatomical Studies of the Vegetative Organs of Rhexia. Bot. Gaz., vol. xliv, p. 22.

8. Jost, L. : Lectures on Plant Physiology. Eng. Ed., I907, p. 314.

9. Jumelle, H.: De l'influence des endophytes sur la tubérisation des Solanum. Rev. Gén. de Bot., t. xvii, 1905 , p. 49.

10. Sablon, L. DU : Sur le tubercule du Tamus communis. Rev. Gén. de Bot., t. xiv, 1902, p. I 45 .

11. Shaw, F. J. F.: The Seedling Structure of Araucaria Bidwillii. Ann. Bot., vol. xxiii, 1909, p. $32 \mathrm{I}$.

12. Solereder, H. : Systematic Anatomy of the Dicotyledons. Eng. Ed., vol. i, p. $5^{81}$.

\section{EXPLANATION OF FIGURES IN PLATES XLII AND XLIII.}

Illustrating Mr. Reed's paper on the Anatomy of some Tubers.

Abbreviations used : cam., cambium; co., cortex; $c k$., cork cells ; c.c., cork cambium; En., endodermis; Ep., epidermis: Hyp., hypoderma ; M., medulla; M.Ph., medullary phloem ; M.ry., medullary ray; $P$. , phelloderm; $P . x y$. ., protoxylem ; $x y$. , xylem; $x y . p .$, xylem parenchyma ; st.g., starch grains; $S$., stolon; $T$., tuber ; s.lv., scale leaves.

Figs. x-6. Solanum tuberosum.

Fig. I. Transverse section of stolon, showing portion of vascular cylinder.

Fig. 2. Longitudinal section of stolon, showing medullary phloem.

Fig. 3. Longitudinal section of tuber, showing isolated strands of medullary phloem.

Fig. 4. Longitudinal section of tuber at its junction with stolon, showing the isolated protoxylem and the meristematic pith cells.

Figs. 5 and $5 a$. Transverse section of tuber, showing origin and development of cork cambium.

Fig. 6. Longitudinal section of tuber, showing isolated strand of medullary phloem.

Figs. 7-14. Helianthus tuberosus.

Figs. 7 and 8. Drawings of young tubers. T., developing tuber; s.lv., scale leaves; S., stolon.

Fig. 9. Transverse section of stolon, showing portion of the vascular cylinder.

Fig. I0. Transverse section of tuber, showing isolation of protoxylem by developing wood parenchyma. 
Fig. II. Transverse section of tuber, showing interfascicular cambium (intf. cam.) forming radial rows of parenchyma cells $(M . r y$.).

Fig. I2. Transverse section of young tuber, showing the early stages of cell division at periphery of mednlla.

Fig. 13. Transverse section of older tuber, showing the radially arranged medullary parenchyma.

Fig. I4. Transverse section of old tuber, showing the isolated strands of xylem and extensive development of xylem parenchyma. 
Annals of Botany,
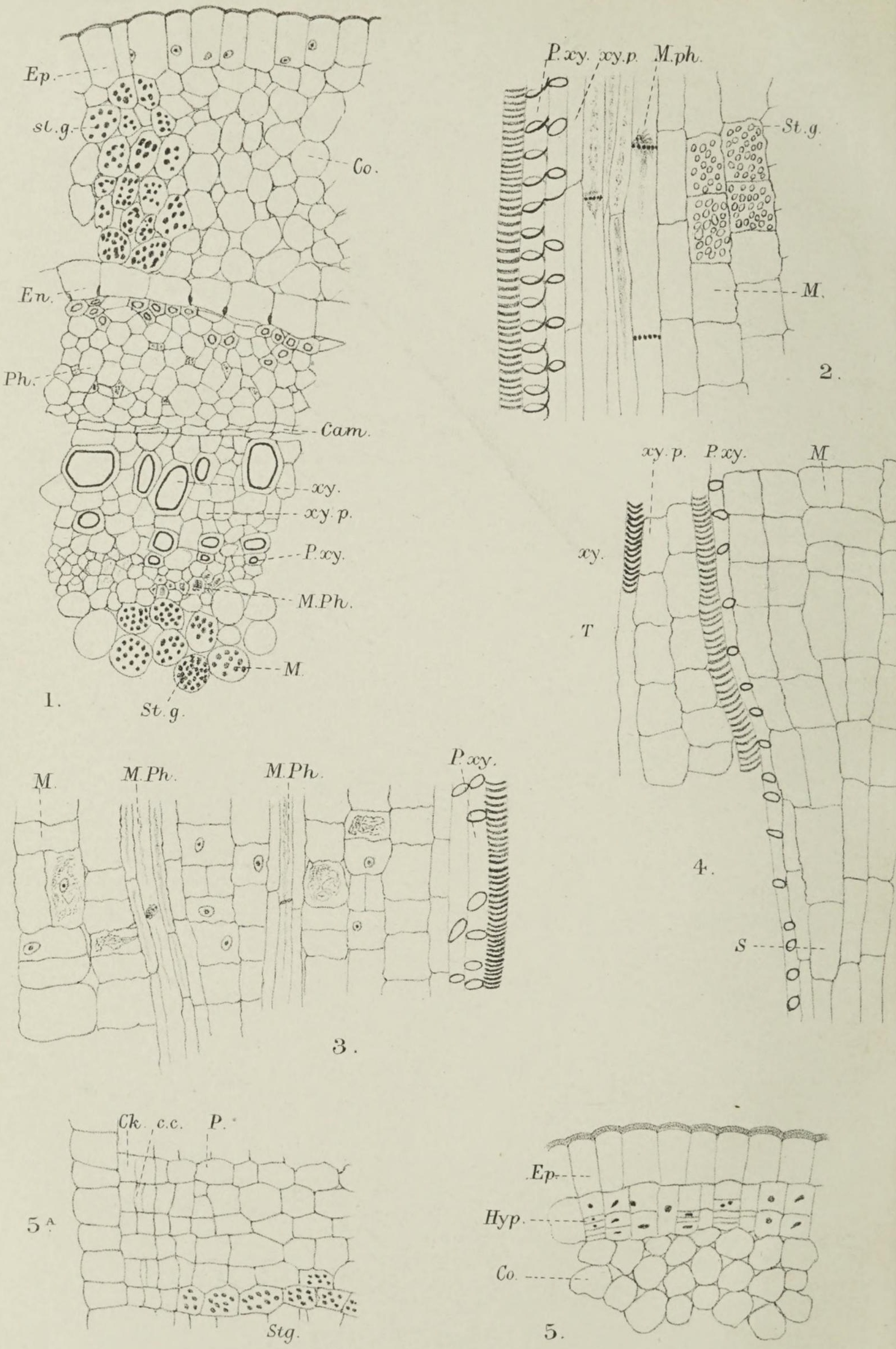


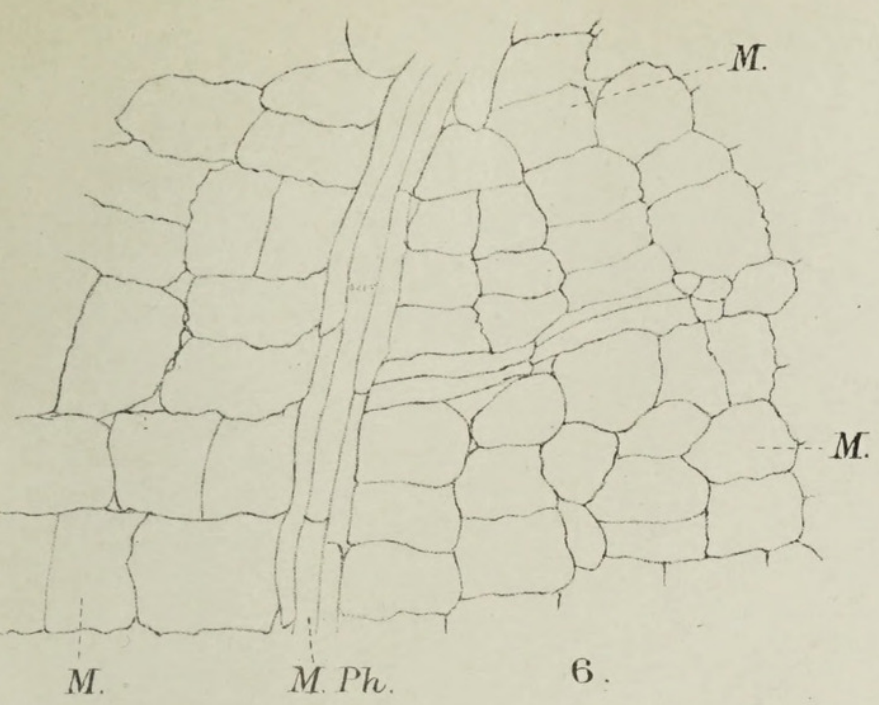

Vol.XXIV,PLXLII.
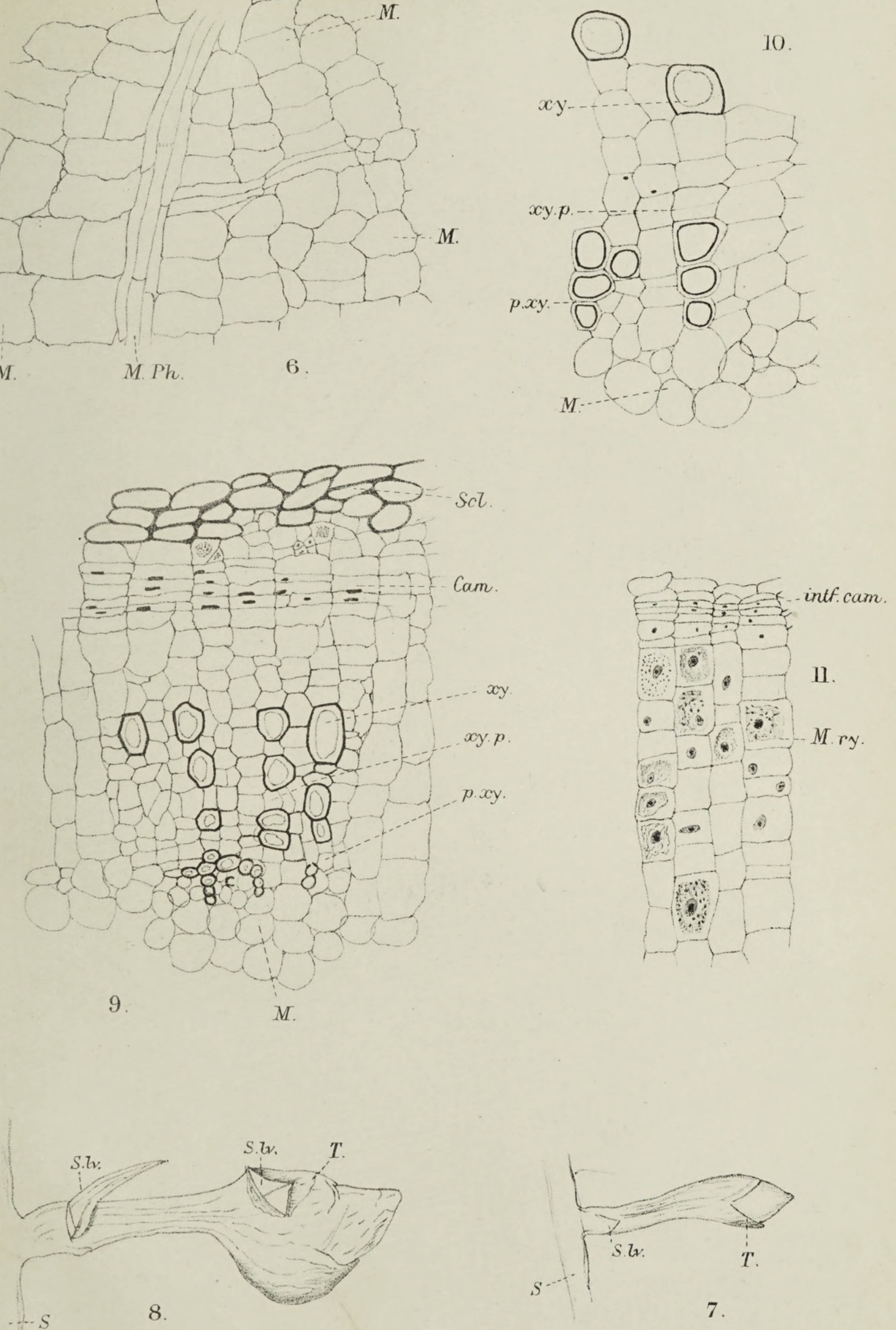

Huthlith et imp. 
Annals of Botany.

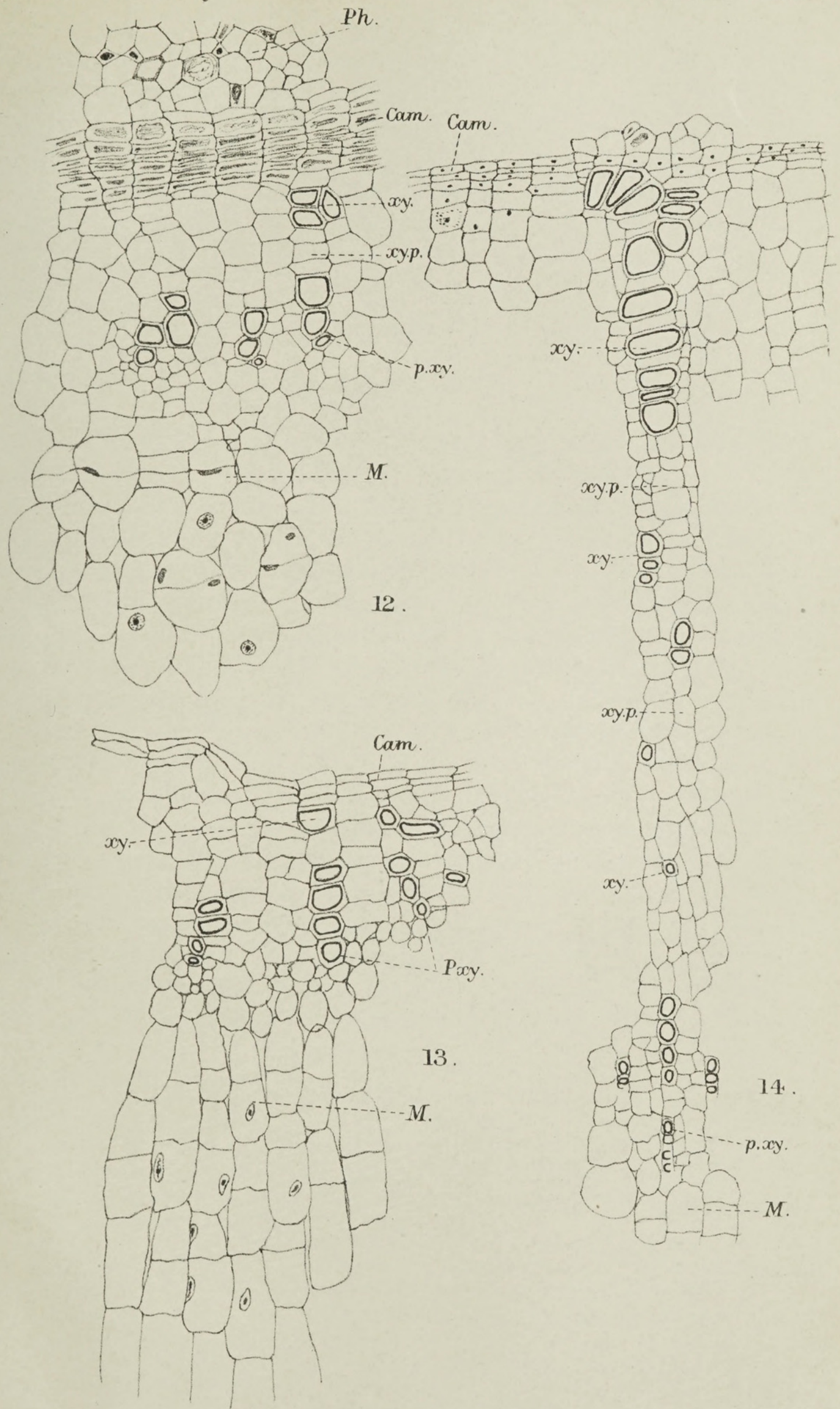

Huth, lith et imp. 


\section{$2 \mathrm{BHL}$ Biodiversity Heritage Library}

Reed, T. 1910. "On the anatomy of some tubers." Annals of botany 24, 537-548. https://doi.org/10.1093/oxfordjournals.aob.a089286.

View This Item Online: https://www.biodiversitylibrary.org/item/262605

DOI: https://doi.org/10.1093/oxfordjournals.aob.a089286

Permalink: https://www.biodiversitylibrary.org/partpdf/319794

\section{Holding Institution}

New York Botanical Garden, LuEsther T. Mertz Library

\section{Sponsored by}

BHL-SIL-FEDLINK

\section{Copyright \& Reuse}

Copyright Status: Public domain. The BHL considers that this work is no longer under copyright protection.

This document was created from content at the Biodiversity Heritage Library, the world's largest open access digital library for biodiversity literature and archives. Visit BHL at https://www.biodiversitylibrary.org. 